\title{
Men battering as the new form of domestic violence? A pastoral care perspective from the Kenyan context
}

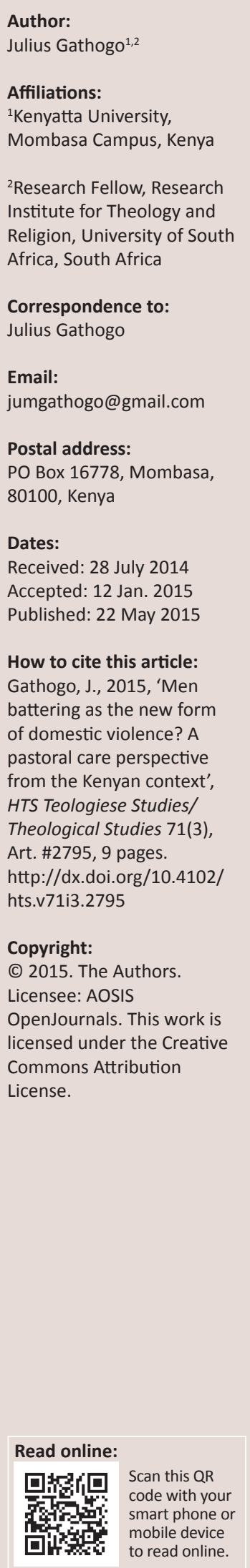

The article sets out to show that gender-based violence is no longer restricted to 'women by men'. Rather society must appreciate that gender battering is a reality across the gender divide, particularly in the 21st century Africa. In its methodology, the article has engaged a theophilosophical approach that involves a social, religious, and a cultural analytical approach. The materials are gathered primarily after interviewing the staff and students from Kenyatta University, Mombasa Campus, and some selected people from the campus surroundings who were consulted orally. To this end, a questionnaire was released in June and July 2012 where about 200 respondents from across the various counties of Kenya were called upon to shed light on men battering in Kenya. In particular, some of the questions that were posed included: Has battering of men by women been part of our African societies from ancient times or is it a new phenomenon? Statistically, who are battered more men or women? How does domestic violence against men manifest itself? What causes it? Why does it sound new to our society? What can we do about it? The article rests on the premise that even though battering of women is more explicit, men battering by women, which takes many forms, has been there for quite some time, albeit unreported. By taking a holistic approach hence 'collective responsibility' across the gender divide, the society can be healed from all forms of gender-based violence.

\section{Introduction: Framing the problem}

On Friday the 10th February 2012, the headlines of the local Kenyan dailies shocked the entire nation when a photo of a disfigured man in his mid-life was displayed. According to the report, the man was mutilated by his wife of 12 years the previous Monday night, for reasons that sent loud whispers through the community regarding the male as being an equally endangered species. In particular, Mr Simon Kiguta, 40, a father of two had just been released from the Intensive Care Unit of the Nyeri Provincial General Hospital following the brutal attack. In his submissions, Mr Kiguta claimed that he was attacked at night by his wife, Ms Juliana Wairimu, 26, with a panga (machete) after he came home drunk, following which the woman disappeared from their matrimonial home, Mihuti Village in Mukurwe-ini District, Nyeri County, only to be arrested by the police a couple of days later. Shortly after this, Mr Francis Muchiri, 34, confessed openly whilst at Mukurweini District Hospital, of the Nyeri County, on February 12, 2012 that he had been battered by his wife. Indeed, Muchiri the father of two sustained serious burns after his their 11-year-old daughter admitted that her father was attacked with hot water by the mother wife allegedly poured hot water over him at their Ruiru home (Njagi 2012b). Of interest to note is that.

Such bizarre cases of men being battered by their wives in Kenya have recently caught the national psyche as it goes against what has been the 'norm,' that is, aggression against women. The magnitude of the injuries also raised eyebrows, and presented the need to find lasting solutions so as to end violence in the family domain. Compounding the problem is that on 09 February 2012, the respected Kenyan newspaper, the Daily Nation, carried a well-researched article, 'Central Kenya top husband-beaters' - in which it highlighted the 'state of the Nation'. In there, photos of the chairman of Maendeleo ya Wanaume (the lobby that fights for the rights of men against domestic violence; Nderitu Njoka) and of another battered man were displayed as he was examining Kevin Muriuki, aged 22, at Nyeri Provincial General Hospital on 08 February, 2012. Kevin, a father of three, was beaten up by a group of people whom he believes had been hired by his wife after a domestic quarrel. Regretfully, Njoka noted thus:

Central Province is the worst place because women are in the habit of beating up their men. We are here to give women the 'red card' that such behaviour has to come to an end ... Men should be respected as family heads, but in Central Kenya, they have been reduced to the role of fathering children before they are dumped. (Njagi 2012a)

Nursing his wounds on his hospital bed, Kevin Muriuki, 22, swore he would 'end his six-year marriage over what he termed torture' from his wife. He went on to show injuries he said were 
sustained, including 'a swollen back, seemingly the result of several whip lashes.' He noted that his head also had bumps, and he was 'limping after three men descended on him. His accusing fingers are pointed at his wife', a 21-year-old beautician, whom he claimed hired his attackers (Njagi 2012b). In his analysis which nevertheless appeared overstated, $\mathrm{Mr}$ Njoka explained that in Central region of Kenya, by February 2012, there were 460000 cases of domestic abuse, of these:

150,000 had reported undergoing emotional abuse while 300,000 cases had been physically assaulted; 300,000 men were battered by their spouses, making the region the worst place in the country for men in wedlock. (Njagi 2012a)

As it turned out, the above attacks opened a can of worms, as more information regarding battering of men by their spouses, outside the Central region of Kenya, began to show in the social media. In Western Kenya, Kisumu, West Kolwa location, Chief Otieno Kabisae reported that he was aware of a number of cases of violence against men by their spouses but regretted that most men preferred to treat their injuries silently so as to avoid being mocked by their fellow men and the society at large (Anyuor 2012). Chief Otieno went on to explain that his area is scattered with incidences where women sometimes threaten their husbands in public meetings with beatings, calling them names, but such men keep quiet to avoid public ridicule. He noted thus:

[S]ome call their husbands 'dogs' and even threaten to 'crush' them in public: such men do nothing, they remain silent. They don't come to us to report such cases officially so that we [can] follow them up. (Anyuor 2012:20)

Similarly, the larger Taita District, in Taita-Taveta County, is also afflicted by battering of men by their spouses. According to the area Gender and Social Development Officer, Daniel Mulonzi, gender-based violence is rampant in the region - a phenomenon that calls for urgent attention (Mnyamwezi 2012).

With this background information, the research set out to establish whether men's battering has been present in African society since time immemorial? How was it handled whenever it occurred? What causes it? Is there anything that can be done to stop it now that it has come into the open? Are we sitting on an explosive time bomb? Are we sitting on a volcano that is ready to erupt? As we focus on the ordeals of Mr Kiguta, the other mentioned men, and the other incidents that captured the national psyche, it is critical to ask ourselves: Has men battering become a new social paradigm for the African society? Or was it there in disguised forms since time immemorial?

\section{Theoretical framework}

Firstly, the article has been applied within a gender theoretical framework which has specifically focussed on the theology of praxis. In turn, gender theology embraces the concept of the 'mending of creation' that takes a critical view on the social transformation of society. In view of this, Mercy Amba Oduyoye (1996:112) says, 'we join in the analysis, deconstruction [and subsequent reconstruction], construction, and advocacy that will bring healing and transformation to our communities'. Secondly, this framework has been applied for the 'mending of creation' in relation to humanity of both men and women who are equally created in God's image (imago Dei); whilst addressing issues of violence such as battering, cheating amongst spouses, oppression of one gender, especially where one gender is economically more endowed than the other, amongst other related issues. Thirdly, this framework has been adopted with the purpose of exploring its inclination of deconstruction and reconstruction theologies (Gathogo 2008:23-62). In his book, From liberation to reconstruction, the renowned Anglophone theologian Mugambi (1995) proposes a theological paradigm shift from liberation theology to reconstruction theology. This aims at social transformation that emphasises personal reconstruction, ecclesial reconstruction and cultural reconstruction after the cold war within the New World Order. The concepts of this paradigm will be utilised in this article in the search for alternative theo-social resources for renovation.

Fourthly, my use of a gender theoretical framework in addressing the plight of battered or abused men is also informed largely by Elisabeth Schüssler Fiorenza, a renowned feminist biblical scholar, who uses the term wo/ men to indicate that 'women/woman' is not a monolithic concept but can equally be used for 'disenfranchised men' (Schüssler Fiorenza 1998:186) - hence (in)justice to women is (in)justice to men and vice versa. The need to use an inclusive framework is thus critical. Undoubtedly, gender violence is a crime that necessarily demands legal redress; nevertheless, it is imperative to theorise and critically reflect on structures and the philosophy that breed it, with intent of dismantling it. It is time to confront it for the greater good of society.

\section{Aim and objective of the article}

The article aims at establishing that there exists men battering in Kenya (and Africa at large) albeit concealed. It thus seeks to find an appropriate model of addressing gender violence that we can use in order to bring about a cohesive and just society for all. Such an approach will have to include the theophilosophical dimensions to address the challenge of men battering, and gender injustices for that matter. In this article, I also want to open up the debate with regard to concealed men battering, which, I argue, has been present, even in the African traditional society from time immemorial, in order to expose the magnitude of the challenge - with the intent to eradicate it from the society once and for all. To this end, the article drives us to own up the challenge of men battering, in as much as we have done in the past especially with regard to women battering. Only then shall we experience the holistic healing of the society.

\section{Methodological considerations}

As noted, the article has engaged a theo-philosophical approach that is largely descriptive and analytical. The materials in this article are informed by the interviews that 
were conducted from about 200 people, both students and staff. In turn, though residing in Mombasa County, the respondents came from the 26 out of the 47 counties that constitute Kenya. That is, Kirinyaga, Mombasa, Vihiga, Nyeri, Kitui, Uasin Gishu, Nyandarwa, Bungoma, Tharaka-Nithi, Nyamira, Kilifi, Kiambu, Machakos, Homa Bay, Kisumu, Taita-Taveta, Murang'a, Embu, Meru, Siaya, Kakamega, Busia, Kwale, Tana River, Lamu and Nakuru. Thus, the information used comes from the interviews, extensive literature reviews, and transcripts (including dairies) as supplementary methods. To this end, some of the concerns of this article (some of which were posed to the interviewees) include: Is men battering rampant in your locality? What causes it? Do battered men readily report it to the relevant authorities, as is the case of battered women? What prevents them from reporting to the relevant authorities? Was it a common occurrence in African traditional society, and if so how was it resolved? Is a theo-philosophical groundwork for a Christian ethic of hospitality an appropriate approach to gender violence?

\section{How men battering manifests itself}

From the interviews (mainly from anonymous interviewees) conducted at Kenyatta University, Mombasa Campus from June to July 2012, it emerged that domestic violence against men manifests itself in a variety of ways. Sometimes it begins by insults to the man in front of their children who sometimes take sides with their mother - particularly when they are first incited against their father. In such scenarios, children in their adolescence may participate in physical attacks against their respective fathers. This may come after their mother first picks a fore-planned or calculated quarrel with her spouse. A case in point is when a woman found her husband having a sexual relation with their maid and as an act of blackmail started beating the shocked couple up (husband and the house help) using any object available in the house, including blunt objects, till they both bled profusely. Considering that (their) culture does not allow an African man to scream if he is ever beaten by a woman or a child, the silent man was eventually battered to death; whilst the screaming house girl broke the door and left naked as she bled copiously, she and the only child in the house lived to tell the story. Other forms of men battering include: slapping; pouring hot water when asleep or pouring hot water over a gullible man; biting areas mostly hidden by clothes; chopping man's genitals; verbal insults; insults before children; slashing; pouring petrol over him and setting him on fire; whips; throwing chairs, benches, stools, utensils and other objects in the house at the man, especially after serious disagreements in the house. In trying to downplay the magnitude of a possible attack from 'a mere woman', some men have failed to address the tension in their respective homesteads only to be ambushed and battered to great proportions.

\section{Causes of men battering}

Interestingly, $70 \%$ of my interviewees pointed out that men battering is more rampant amongst Christians than amongst
Muslims. In other words, it is very rare to find a Muslim woman battering her husband. Interestingly, Simon Kiguta's wife, Juliana Wairimu is a Presbyterian Christian and an ardent member of the 'purist' Women Guild. Simon Kiguta, who interestingly became the face of husband battery in Kenya when his picture was circulated on all forms of media, after being admitted to hospital with deep panga (machetes) cuts, upon being discharged from the hospital, six months later (22 July 2012), noted that he was deeply asleep when his wife had attacked him. He was therefore defenceless. He added that his case could not be counted as husband battery because he was caught unawares. This contradicted the popular beliefs that Kiguta was overpowered by his 'stronger' half and thus the beating. However, in his bid to protect patriarchy and the shame he now undergoes as a result of 'being beaten by a woman', he gave a different version of the story. In a nutshell, his wife had mercilessly cut his head with the intention of killing him. Kiguta noted that parts of his body have never made a full recovery. After he had been discharged from hospital he went to live with his father, who, like in his childhood days, became his provider for his every need before he healed completely. He was however quick to add that Nyeri women are not what they were portrayed to be (violence lovers). He noted rightly that any woman regardless of the community she comes from can beat the husband. Asked if he would remarry, Kiguta said he would consider it after he made a full recovery, since he could not, at the time, provide for a wife.

Significantly, 25\% of my respondents noted that the main cause for men battering was the reckless use of alcohol (traditional liquor popularly called kairaci) mainly by men; $15 \%$ felt it was the failure to provide for the family; $8 \%$ felt it was unfaithfulness in the marriage (popularly called mipango ya kando); $7 \%$ felt it was general poverty; and 3\% noted that it had something to do with the denial of conjugal rights. Other causes of men battering cited include: denial of conjugal rights by drunkard or busy spouses; marriage to older women who underrate younger spouses; insults to women; retaliation against men who keep on beating their wives; parental interference especially on both sides; poor upbringing; general disagreements over matters of sexuality; children; money or/and wealth. Again, when a sexually promiscuous man infects a faithful woman with sexually transmitted diseases, a woman may get out of her senses and wildly attack an unsuspecting spouse - and thereby injure him fatally. The latter can however apply to any of the spouses.

\section{Reasons that prevents battered men from reporting}

During the interviews, a question was posed: 'Do men report to the relevant authorities when battered by women?' In this, $70 \%$ of my respondents gave an affirmative ' $\mathrm{No}^{\prime}$. Asked why the situation occurred, various reasons where given. These included: cultural reasons; religious leadership that advises the couple to 'seek the face of God' rather than 'washing dirty linen' in public; parents fear of embarrassment; male 
ego; close friends who prefer to downplay the magnitude of the problem; fear of being laughed at; fear of the taboo or/and anathema associated with the cultural dictates of the African societies; fear of divorce in cases where the man relies on the 'rich' woman for his daily upkeep; and the embarrassment that goes with shame and exposure of being seen as a 'weak man' - in a culturally sophisticated society. The fear of reporting to the relevant authorities is further compounded by the fact that in most communities of Africa, it is an abomination to see a man crying after being beaten by a woman. In such scenarios, a 'crying man' would loose status due to the cultural barriers and stigma attached to it. Others feel guilty for being irresponsible to their families, hence the silence amidst battering. This makes it difficult for the battered man to scream for help.

\section{Men battering in African traditional societies}

From my interviews, it was established that in most of the largely patriarchal African societies, men battering was rare and attracted heavy penalties whenever it occurred. Why? Firstly, amongst the Kikuyu a person became a Mundurume (adult man) after the weaning rites around the age of 15-18. Being a Mundurume is not just a promotion from childhood to adulthood but more importantly it goes hand-in-hand with psycho-social responsibilities.

Among the responsibilities included being a community soldier. In other words Mundurume was first and foremost a leader, a warrior, a responsible person, or 'a security officer' of the community who, as a matter of stipulation, had to have a higher calling, to protect the community at all costs. (Gathogo 2007:11)

When the leopard or a hostile neighbour came to attack the village, it was the youthful or the strong men who went to counter attack, hence it was a taboo to see a battered soldier, let alone being battered by a woman in a patriarchal society (Gathogo 2012a:447-470). This would not only annoy the living but the ancestors and the unborn - all of whom were considered as members of the extended family and society at large and such an abomination would be treated as a taboo. It is comparable to having sexual relations with a person who had not undergone the ritual of circumcision, amongst the Kikuyu. If it happens, Jomo Kenyatta noted that, 'a man or woman must go through a ceremonial purification, korutwo thahu or gotahikio megiro - namely, ritual vomiting of the evil deeds' (Kenyatta 1938:132-133). These ceremonial purifications went hand-in-hand with other forms of punishment against the errant wife. According to Mzee James Gitonga, errant wives would be returned to their parents after the council of elders had established clearly that they actually battered their husbands. In such scenarios, a woman would be forced to return to her parents with her children and could, if she ever had a chance, be remarried as a gichokio (literally a returned person or thing; Gitonga 2012, pers. comm.). In turn a gichokio refers to a woman who bears children out of wedlock and/or before marriage; hence a woman who battered her spouse was treated in the same way. To return her with children was meant to 'uproot' the bad seed from the family. She was to remain unmarried until the dowry (which was in form of cows, goats and local muratina brew) was returned. If the family of the battered man was too poor to return the dowry, she would remain unmarried indefinitely and/or forever. Unfortunately, such heavy penalties were never administered to men who battered their wives.

Amongst the Banyore (Luhya) of Western Kenya, whenever it was established that a woman battered her spouse, elders from both sides would be summoned. Here, the issue at hand would be tabled. If it was established beyond any reasonable doubt that she indeed battered her spouse, the house was ritually demolished; and another one could be rebuilt if a man wanted to remarry. Being a communal issue that affected the society, it meant that the man could be assisted to rebuild the house if he wished to remarry. In some cases, a woman who battered her husband could be warned publicly; and if she was willing to change, she could be accepted back into the community. Failure to change however meant that, as in the case of the Kikuyu, she could be disowned by the society, her house be demolished and she would even be disallowed from drawing water from a common spring. She was isolated from the rest of society. Again, the same 'law' did not apply to men who battered their spouses, even though lesser penalties could be imposed on such men. In some African societies, such men-battering women would be cursed communally, 'never to get husbands' or prosper during their lifetimes. The same penalty was however not given to men who battered wives.

\section{Theo-philosophical implications of men battering}

In my researches, it became clear to me that battering of men in Kenya is more rampant in areas where people are largely Christians. Asked to explain where battering of men is more rampant, $70 \%$ of my interviewees felt that it is more common in areas where men and women confess the God of Christendom. Twenty percent explained that it is more rampant in areas dominated by Muslims, whilst $10 \%$ said it is rampant in areas that are dominated by adherents of African indigenous religions. Certainly, this has several implications. Firstly, with the Kenyan population being predominantly Christian (over $80 \%$ ), the fact of men battering is seen as being more common in the so-called 'Christian zones' than in Muslim dominated regions is quite understandable.

Secondly, David Barrett's prediction, in 1982, that Africa (Kenya inclusive) will be the continent with an estimated Christian population standing at more than $50 \%$ of the overall population of about 750 million people, ought to be rethought afresh (Barret 1982). For, in view of the secularisation of Christianity that is facilitated especially by the forces of globalisation, we cannot know how authentic our brand of Christianity will be. Or was not Christianity in the past misused to facilitate wretched experiences such as slavery and slave trade; as basis for racial segregation during the era of apartheid; the Kanugu Massacre in Uganda where 
a Christian group in Western Uganda was burnt to death by their leader when his prophecy of the end of the world on 31st December 1999 did not come to pass? Certainly, the violence that took place after the 27 December 2007 Kenyan elections, was in areas that are largely Christians (refer to Rift Valley, Nyanza, Central Kenya and Nairobi areas); and even then, the figures from Transparency International (see Gathogo \& Phiri 2009:216-241), show some of the most corrupt countries of Africa are nations that are predominantly Christian (refer to Kenya at $80 \%$, Nigeria at $46 \%$, Burundi $65 \%$, Equatorial Guinea 93\%, amongst others). Similarly, the May 2008 xenophobic attacks in South Africa took place in slums where the population is predominantly Christian. Further, considering that the Rwandan genocide of 1994 took place in a predominantly Christian country (at $90 \%$ ), shows that there is something wrong with African Christianity (Gathogo $2012 b: 81-83)$. In the nature of things, there is a need for African Christians themselves to understand Christianity in Africa - with the intent to making it better. Indeed, the numerical growth of Christianity in Africa, Kenya in particular, is not convincingly matched proportionately with the understanding of the same by African Christians. In view of this, unveiling the men-battering phenomenon requires African Christians to understand Christianity in Africa, with the intent to rediscovering where the 'rain began to beat us', and eventually appreciate Christ's love for the 'Other' - as hallmarks of being authentic Christians.

Thirdly, we must appreciate that the men-women battering phenomenon symbolises the 'state of the nation' - where the 'strong' feel obliged to completely destroy the 'weaker' ones. Indeed, this is a clear display of the 'psychology of the strong' where the 'weak ones' must be destroyed at all cost. A case in point is seen in the various militant groups in Kenya and the rest of the tropical Africa, such as: the Mungiki (meaning multitude or mass movement amongst the Kikuyu who terrorise villagers by extortions); Chinkororo (who terrorise people in Western Kenya though claiming to be a vigilant group); Kamjesh (who in the 1990s, used to terrorise people in Nairobi by claiming they were protecting their patron politician); the Mombasa Republican Council (who wants to secede from Kenya through violent means; Benyawa \& Masha 2012); Boko Haram (who are known for attacking Christians and bombing churches in Nigeria); AlShabaab, al-Mujahedeen al-Muhajereen (migrant jihadists) and al-Qaeda terrorist networks. In such scenarios we are easily tempted to assert our new-found strength against those whom we consider 'weak'. Such scenarios ought to be collectively deconstructed in order to build a habitable society for all.

\section{Towards a violence free society Gender mainstreaming as a key strategy}

Though specifically meant for women, the Fourth World Conference on Women held in Beijing (United Nations 1995), adopted as Resolution 1, the 'Beijing Declaration and Platform for Action' which has lessons across the gender divide. Firstly, it sought to advance the goals of equality, development and peace for all wo/men everywhere in the interest of all humanity. Secondly, it also recognised that gender disparities are exacerbated by the increasing poverty that is affecting the lives of the majority of the world's people, in particular wo/men and children, with origins in both the national and international domains. Thirdly, it reiterated its commitment to the:

equal rights and inherent human dignity of wo/men and men and other purposes and principles enshrined in the Charter of the United Nations, to the Universal Declaration of Human Rights and other international human rights instruments. (United Nations 1995)

In particular the Convention on the Elimination of All Forms of Discrimination against $\mathrm{Wo} /$ men and the Convention on the Rights of the Child, as well as the Declaration on the Elimination of Violence against Women and the Declaration on the Right to Development. Fourthly, it dedicated itself unreservedly to addressing gender related constraints. It realistically noted that such requires urgent action in the spirit of determination, hope, cooperation and solidarity across the gender divide, as they carry on the agenda of gender mainstreaming into the 21st century (United Nations 1995).

In a nutshell, the Beijing Declaration and Platform for Action (United Nations 1995) recognised gender mainstreaming as a key strategy to reducing or eliminating gender disparities across the board. In as much as it informs women, it also informs the entire society. Clearly, this principle of human dignity, implied in the Beijing Declaration, affirms that God is the source of all life. It has its strongest roots in Immanuel Kant's (1785) moral philosophy that affirms the inherent worth of human beings. Certainly legislation is not enough to promote gender justice in our society, nor merely arresting or even jailing of the perpetrators of gender battering. Rather, the biased categories of gender analysis should be replaced with new, holistic images which emphasise the whole humanity of both sexes (Ackerman 1992). In turn, gender analysis is a tool to diagnose the significant differences across the gender divide. It insists on their actual activities, needs, access to development benefits and decision-making. It studies the linkages and factors that inform the society in the larger socio-environmental context. Whereas sex roles are God given or are biologically determined, gender roles as human or cultural constructions can be changed. This understanding may help to bridge the big gap that stands between men and women, hence cases of violence and tensions that are occasionally experienced. This further drives us to focus on relational anthropology that stands opposed to alienation across the social or gender divide; it shifts binary oppositions such as man versus woman, culture versus nature, strong versus weak, equal versus supplement amongst others. Certainly, the usage of the post-structural theories on language, subjectivity, institutions, and social processes in order to understand existing power relations and eventually identify areas that beg for change should be propped up. As Denise Ackerman notes, language has the capacity to constitute social and cultural realities (Ackerman 1992:69-74). 
Therefore, the language we use when speaking or writing does not only have grammatical and/or orthographical implications but also reflects the social realities and dominant discourses around us. In mainstreaming gender thus, the choice of language, whether at home or in our working places will be critical. In particular, language that tends to deny that men and women are joint bearers of the image of God (imago Dei) should be downright rejected.

\section{Appealing to the notion of perichoresis}

As a noun, the Greek term perichoresis, is derived from the verb choreo, which is used to express the idea that each person participates in others. It was first used in a Trinitarian context by Pseudo-Cyril in the 6th century CE and later in the 8 th century by John of Damascus. The first theological use of the verb perichoreo was used to discuss the divinity and humanity of Christ by Gregory of Nazianzus and Maximus the Confessor. The main objective was to show the reciprocity and exchange between the divine and human actions in the person of Christ (Fiddes 2000:73). In a nutshell, the notion of perichoresis takes up the words of Jesus in the Fourth Gospel: 'believe me that I am in the Father and the Father is in me' (Jn 14:11). Certainly:

Perichoresis is a term in Christian theology first found within the Church Fathers but now reinvigorated among contemporary theo-philosophical thinkers such as C. Baxter Kruger, Jurgen Moltmann, Miroslav Volf and John Zizioulas, amongst others'.

(Absolute Astronomy n.d.)

An appeal to the notion of perichoresis (or circuminsession or interpenetration), in order to understand gender violence, is to learn from the threefold nature of the Trinity - the mutual interpenetration and indwelling of God the Father, the Son and the Holy Spirit. In view of this, the idea of reciprocity and mutual indwelling and penetration of the persons is emphasised. In other words, the permeation of each person by the other, 'their co-inherence without confusion' in the Trinitarian trajectory is critical to understanding the importance of our human fellowships and interdependence particularly amongst the spouses hence gender-based violence contradicts the philosophy behind perichoresis (Fiddes 2000:71).

Beyond perichoresis is the Greek word circumincessio, which is used to describe the persons of the Trinity, namely that of a divine dance. Certainly, this is a powerful metaphor which is often evoked in recent Trinitarian studies. In particular, Elizabeth Johnson (1992:220) writes that 'a divine round dance modelled on the rhythmic, predictable motions of the country folk dance are one way to portray the mutual indwelling and encircling of God's holy mystery.' She says that:

$[A]$ perichoretic movement summons up the idea of all three distinct persons existing in each other in an exuberant movement of equal relations: an excellent model for human interaction and freedom and other regards. (Johnson 1992:221)

For her, the idea of the divine community as a divine dance (circumincessio) serves as inspiration for human community, as well as a prophetic challenge to human relations and social structures that subordinate and marginalise (Johnson 1992:221). She further argues that the symbol of a triune God invites people from all religious and denominational persuasions to appreciate one another as a community 'in kinship with the earth, equal partners in mutual relationship, sent to bring the world into this dance of life' (Johnson 1997:309). This idea of a divine dance is also captured by Catherine Mowry LaCugna (1991) in her book, God for us: The Trinity in Christian life. LaCugna finds the metaphor (circumincessio) effective in addressing discrepancies in society, particularly in deconstructing an oppressive hierarchy. LaCugna (1991:272) says, ' $t$ t]here are neither leaders nor followers in the divine dance, only an eternal movement of reciprocal giving and receiving, giving again and receiving again'. From the above examples, it is clear that Trinitarian theologians view the concept of perichoresis as a creative image that is capable of inspiring an appreciation of interdependence, relatedness, particularity and mutual co-existence for humanity and the order of creation in general. Gender-based violence in Kenya and the rest of tropical Africa has a motivation to draw from these insights.

Rather than just seeking help from the religious leaders, the police or even seeking legal redress as most interviewers pointed out to me, it is critical for married couples to appeal to the notion of perichoresis. In turn, they should learn from it, considering that most cases that experience gender battering are in the so-called 'Christian zones'. Central to perichoresis, is the notion of openness to the other. Indeed, Origen's (cited in Rusch 1980:15) contribution to the understanding of perichoresis, is outstanding. For him, the essence of God is Trinitarian, thus preserving otherness as not simply an external attribute of God but as constitutive of God's nature. To engage the other, the notion of difference must be respected and preserved. One cannot engage the other when that other is only a reflection of the same. The Father cannot be the Father unless there is a Son and a Spirit. The love the Father has for the Son cannot be true love unless such love rests in the Spirit. In view of this, only in the Trinity can perfect mutual reciprocity be achieved. On the other hand, human beings can attempt to enact reciprocal love through justice practiced in society. But human society is never perfect, hence the enactment of laws, punishment and constant revision of the legal system in light of growth in human experiences and knowledge.

\section{Appealing to an ethic of hospitality}

Another critical step towards a violence-free society is an appeal to the ethic of hospitality. In turn, the word 'hospitality' is derived from the Latin noun hospitium or hospitalitas which stems from hospes meaning both 'host' and 'guest' (Gathogo 2011). It is concerned with the way in which we treat our relatives, friends and strangers - a phenomenon that involves shared partnership and mutual relationship between all the characters involved. It is 
critical to point out that originally, the stranger amongst the Greeks, like in most cultures, did not receive a welcome, instead, the relationship with him or her was generally hostile. Why? A stranger was considered an enemy because of the fact of being unknown to the inhabitants of the area into which he or she moved. This hostility was fuelled by the perception that the stranger possessed some magical powers which would be detrimental to their wellbeing. To that end, a stranger was potentially dangerous, hence the need to confront him or her with violence which could result in death. In such scenarios, a stranger had no human rights to count on. In the course of time, the tendency towards a friendly relationship evolved. In the new paradigm that emerged, a stranger was now seen as a messenger of the gods, and for fear of the gods the stranger was accorded welcome and the much needed protection. This attitude is present in both the Old and the New Testament. To this end, the writer of Leviticus tells the Israelites:

If you have resident aliens in your country, you will not molest them. You will treat resident aliens as though they were nativeborn and love them as yourself - for you yourselves were once aliens in Egypt. I am Yahweh your God. (19:33-34)

The Israelites therefore welcomed strangers not only because of their belief that God could visit them in the person of a stranger - who brought blessings along with him or her - but mainly out of gratitude for their experience of hospitality whilst they were in Egypt and during their exodus out of Egypt, as well as their wandering in the desert. The ethic of hospitality continues as a major theme in the New Testament. In Romans 15:7, St. Paul tells Christians: 'Accept one another, and then, just as Christ accepted you, in order to bring praise to God.' Again in Romans 12:13, he says, 'look for opportunities to be hospitable.' Similarly, in ancient African society, the ethic of hospitality defined the ideal aspect of existence; therefore a good person was necessarily hospitable - not inhospitable, stingy or violent. Uzukwu (1988) attempts to explain the ethic of hospitality in providing a liveable environment when he says:

Despite the destabilization of traditional life by colonialism, foreign world views, technology and modern living, ... African hospitality has held rather well to the extent that it could be described as a way of being an African. (p. 158)

Uzukwu however fails to appreciate the increasing cases of gender battering, general violence, xenophobia, banditry, terrorism, political clashes and tensions amongst various ethnic groups in tropical Africa - as modern challenges to hospitality. Nevertheless, in the light of increased cases of gender-based violence especially amongst the spouses, an appeal to an ethic of hospitality is critical. This can be done at home, in religious and educational institutions and at all social functions - where we remind ourselves about the importance of the ethic of hospitality - and where it can take us, as a family, as a nation and/ or as individuals. Certainly, hospitality displayed by thee 19th and 20th century missionaries has lessons for Africa of the 21st century as she struggles with various forms of violence. Clearly, the missionaries left their comfort zones in industrialised Europe and came to offer their theoeducational missions to Africa - they thus provide us with a good example on how to uphold the ethic of hospitality. Indeed, the history of Christian missionaries of the 19th and 20th centuries remains an informative and inspiring part of our African history - which must necessarily inform us again and again about self-sacrifice and a general concern for the 'other'. Similarly, hospitality that is displayed by parents during a person's formative stages, and even the societal hospitality, has taken us as individuals, to where we are today. Hence, in our success as individuals and as a society, we are beholden to the care and hospitality that we received during our infant stages. Again, for hospitality to have value for the society, it has to be dispensed with maturity, responsibly and understanding, hence prudence. In view of this, drunken spouses who fail to provide for their families, because of the reckless consumption of liquor go against the ethic of hospitality - these are acts of irresponsibility amongst men or women that smack of destruction in any given society. Equally so, the reckless drinking of liquor is a form of irresponsibility just as every other form of battering - these are both acts of inhospitality. In any case, St. Paul in 1 Timothy 5:8 builds the case for a responsible society of men and women in his assertion that anyone who does not provide for his (or her) relatives, and especially for members of his (or her) family ultimately denies the Christian faith and is therefore worse than an unbeliever.

\section{The legal route versus pastoral route}

In contemplating the idea of pursuing the legal route, it is critical to appreciate that it is not easy to just rush to court in a bid to seek orders to compel a non-cooperative spouse to perform his or her conjugal responsibilities. It appears more appropriate to consider seeking professional assistance from a qualified marriage counsellor or even the services of a trained religious practitioner and discuss issues. Clearly, the law treats denial of sexual intercourse amongst spouses as cruelty according to precedence set by the English case of Sheldon v. Sheldon in 1966 (Sheldon 1966). According to the case, the court granted a wife orders to divorce her husband for denying her conjugal rights, which amounted to cruelty, which is a ground for divorce. According to Lord Denning, the Judge, the persistent refusal of sexual intercourse by the husband for long without excuse caused grave injury to the health of his wife (Sheldon 1966). He argued that spouses have rights and responsibilities that should be fulfilled in matrimony. Legally, local courts can apply such precedents (landmark judgements) by courts in Commonwealth countries. In my view, the pastoral route would serve better.

\section{Conclusion}

In conclusion, the article began by locating the problem that informed the research that has culminated in this article. The author was able to locate the battering of men by women as a 
reality that African societies have tended to ignore in place of women battering by men. Both scenarios have been portrayed as unfortunate developments that must be eradicated in order for us to live in a habitable and prosperous society. It cited the case of Simon Kiguta who was brutally attacked by his wife Juliana Wairimu, in Nyeri County of Kenya in February 2012, when he came home drunk. As he slept Wairimu used a panga (machete) to disfigure him. In commending him for breaking the silence regarding men battering in Kenya and African context at large, where patriarchal cultural dictates expect a battered man to keep quiet so as to avoid ridicule from the neighbourhoods, Kiguta, became the face of men battering.

After the staff and students of Kenyatta University, Mombasa Campus were interviewed, it was established that Kiguta's case is not an isolated one; he symbolises the nature of inhospitality and hostility that defines tropical Africa albeit in silence. A theo-philosophical attempt at addressing the challenge was attempted. To this end, the article attempted to make some clarifications. Firstly, there is a need for African Christians to understand African Christianity - in order rediscover where the 'rain began to beat us'. In considering that gender-based violence takes place largely in the so-called Christian environments, it is crucial to appreciate that only an understanding of the nature of our African Christianity will help us improve on its quality. Secondly, violence to men or women is injustice to all, hence the need to eradicate it. Thirdly, though some ancestral resources are important in addressing gender violence, it is vital to assess them carefully unless we institutionalise matriarchy or patriarchy, and thus fail to address gender-based violence across the board. Fourthly, though specifically meant for women empowerment, the Beijing Declaration and Platform for Action (United Nations 1995) with its resultant emphasis on equality, development and peace across the gender divide has important lessons for society at large. Fifthly, there is an urgent need for gender mainstreaming that begins by appreciating the humanity of all people. Considering that language has the capacity to constitute social and cultural realities, the need to use it purposively to promote relational anthropology is vital.

Sixthly, an appeal to the notion of perichoresis (the oneness of the triune God) was shown as a necessary concept that will help in addressing gender-based violence. Further, perichoresis was shown as a creative image that is capable of inspiring an appreciation of interdependence and mutual coexistence for humanity, thus gender-based violence in Kenya and the rest of the tropical Africa has a motivation to draw from it. And lastly, an appeal to an ethic of hospitality was discussed as essential in arresting the problem. In particular, hospitality of the ancient Greeks, the Bible and the African heritage was cited to show the importance of inculcating the virtue (of hospitality) across the gender divides. In any case, St Paul tells his audience (including spouses) to accept one another just as the hospitable Christ accepted them despite their shortcomings and irrespective of who they are (cf. Rm 15:7). Similarly, an African ethic of hospitality dictated that goodness is synonymous to being hospitable to the 'other'.

\section{Acknowledgements}

I would like to thank the staff and students of Kenyatta University who gave me crucial information after I released my questionnaires. The respondents came from the 26 out of the 47 counties that make up Kenya spoke volumes, and clearly represented the 'state of the nation'. With this publication, I hope it will go a long way in addressing the status quo for the betterment of our society of men and women who walk through the valley of death.

\section{Competing interests}

The author declares that he has no financial or personal relationships which may have inappropriately influenced him in writing this article.

\section{References}

Absolute Astronomy, n.d., s.v. 'Perichoresis', viewed n.d., from http://www. absoluteastronomy.com

Ackerman, D.M., 1992, 'Defining our humanity: Thoughts on feminist anthropology', Journal of Theology for Southern Africa 9(79), 69-74.

Anyuor, N., 2012, 'Unreported cases of male battering in Nyanza', The Standard, viewed n.d., from http://www.standardmedia.co.ke/?articlelD=2000052337\&sto ry_title=Unreported- cases-of-male-battering-in-Nyanza

Barret, D. (ed.), 1982, World Christian encyclopaedia, Oxford University Press, Nairobi.

Benyawa, L. \& Masha, J., 2012, 'MRC's threat escalates as it recruits children', The Standard, viewed 22 July 2012, from http://www.standardmedia. co.ke/?articleID $=2000060153$

Fiddes, P., 2000, Participating in God, Westminster/John Knox Press, Louisville.

Gathogo, J., 2007, 'The use of ancestral resources in combating HIV and AIDS: Mundurume's task', Journal of Constructive Theology 131(1), 5-24.

Gathogo, J., 2008, 'Genesis, methodologies, and concerns of African theology of reconstruction', Theologia Viatorum 32(1), 23-62.

Gathogo, J., 2011, Christ's hospitality from an African theological perspective, Lambert Academic Publishing, Saabrücken.

Gathogo, J., 2012a, "'Chasing a leopard out of the homestead": Mundurume's task in the era of HIV and AIDS', in E. Chitando \& S. Chirongoma (eds.), Redemptive masculinities: Men, HIV and religion, pp. 447-470, WCC Publication, Geneva.

Gathogo, J., 2012b, 'Post-Liberation theology: A critical appreciation', in I.M.T. Mwase \& E.K. Kamaara (eds.), Theologies of liberation and reconstruction: Essays in honour of Prof. J. N. K. Mugambi, pp. 81-83, Acton, Nairobi.

Gathogo, J. \& Phiri, I., 2009, 'Xenophobia/Afrophobia in post apartheid South Africa: Strategies for combat', Theologia Viatorum 33(2), 216-241.

Johnson, E.A., 1992, She who is: The mystery of God in feminist theological discourse, Crossroad, New York.

Johnson, E.A., 1997, 'To let the symbol sing again', Theology Today 54(3), 299-311. http://dx.doi.org/10.1177/004057369705400302

Kant, I., 1785, The groundwork for the metaphysics of morals, transl. T.K. Abbott, Hackett Pub. Co., Indianapolis.

Kenyatta, J., 1938, Facing Mount Kenya, East Africa Education Publishers, Nairobi.

LaCugna, C.M., 1991, God for us: The Trinity in Christian life, Harper San Francisco, New York.

Mnyamwezi, R., 2012, 'Husband battering also widespread at the Coast', The Standard, viewed 08 July 2012, from http://www.standardmedia.co.ke/?articleID=2000052 359\&story_title=Husband-battering-also-widespread-at-the-Coast

Mugambi, J.N.K., 1995, From liberation to reconstruction, East Africa Education Publishers, Nairobi.

Njagi, J., 2012a, 'Central Kenya 'top husband-beaters", Daily Nation, 09 February 2012, viewed 09 July 2012, from http://www.nation.co.ke/News/Central+Kenya+t op+husband+beaters/-/1056/1323646/-/14l56j7z/-/index.html

Njagi, J., 2012b, 'My wife scalded me, says man', Daily Nation, February 12, viewed 26 July 2012, from http://allafrica.com/stories/201202130005.html.

Oduyoye, M.A., 1996, 'Feminist theology, Africa', in L.M. Russell \& C. Shannon (eds.), Dictionary of feminist theologies, pp. 110-121, Kentucky, John Knox Press, Westminister. 
Rusch, W.G. (ed.), 1980, The Trinitarian controversy, Fortress Press, Philadelphia. Schüssler Fiorenza, E., 1998, Sharing her word: Feminist Biblical interpretation in context, Beacon Press, Boston.

Sheldon, R.F., 1966, 'No conjugal rights, I want to go to court', viewed 26 July 2012 from http://www.baseball-reference.com/players/s/sheldro01.shtml
United Nations, 1995, Report of the Fourth World Conference on Women, Beijing 4-15 September 1995, viewed 26 June, 2012, from http://www.un.org/esa/gopherdata/conf/fwcw/off/a--20.en

Uzukwu, E.E. 1988, 'Missiology Today: The African situation', in E.E. Uzukwu (ed.), Religion and African culture: Inculturation - A Nigerian perspective, pp. 151-163, Snaap Press, Enugu. 